\title{
Sanal Tarih Yazıcılığının Sorunları: Prof. Ohannes Manisaciyan ve Merzifon Anadolu Koleji Müzesi
}

\section{Dilemmas of Web-based Historiography: Prof. J.J. Manissadjian and the Anatolia College Museum in Merzifon, Turkey}

Emine Alçıtepe ve Galip Alçıtepe. Anadolu’nun Kaybolan Renklerinden Bir Doğa Bilimci J.J. Manissadjian. İstanbul: Paros Yayıncılık, 2019, 19x25.5 cm. 220 s. (80 resim, tabl., kaynakça) ISBN 978-605-80323-0-9.

Şeref Etker ${ }^{1}$ (i), Gönenç Göçmengil² (i)

'Dr., Istanbul, Türkiye

${ }^{2}$ Dr. Istanbul Üniversitesi-Cerrahpaşa, Jeokronoloji ve Jeokimya Laboratuvarı, İstanbul, Türkiye

ORCID: S.E. 0000-0001-6966-8816; G.G. 0000-0002-1955-8026

Sorumlu yazar/Corresponding author:

Şeref Etker,

Istanbul, Türkiye

E-posta/E-mail: serefetker@gmail.com

Başvuru/Submitted: 04.02 .2020 • Kabul/Accepted: 10.05 .2020 • Online Yayın/Published Online: 03.07 .2020

Atıf/Citation: Etker, Şeref, ve Göçmengil, Gönenç. "Sanal Tarih Yazııılığının Sorunları: Prof. Ohannes Manisacıyan ve Merzifon Anadolu Koleji Müzesi.” Osmanlı Bilimi Araștırmaları 21, 2 (2020): 403-422.

https://doi.org/10.26650/oba.202001

On dokuzuncu yüzyılın ikinci yarısında, özellikle II. Abdülhamid döneminde, Osmanlı İmparatorluğu'nda Amerikalı Protestan misyonerler tarafindan kurulan okul ve hastanelerin bir bölümü ABCFM (American Board of Commissioners for Foreign Missions) örgütüne bağlıydı. ABCFM örgütünün tarihsel arşivlerinin okurlara açılması, ${ }^{1}$ bu kuruluşları konu

1 ABCFM belgelerinin bulunduğu arşivler: Ankara Bilkent Üniversitesi Tarih Bölümü ABCFM Projesi (American Board of Commissioners for Foreign Missions upon the Near East) Mikrofilm Koleksiyonu (1817- 
alan çalışmaların yapılmasına olanak sağlamıştır. Ancak, söz konusu yayınlarda ABCFM belgelerinin seçici bir biçimde kullanıldı̆̆ı; yazarların kavrama, irdeleme ve doğrulama yerine varsayım, çıkarsama ve kestirimlerle bir sonuca varmaya çalıştıkları dikkati çekmektedir. ${ }^{2}$ Araştırma yöntemleri - denilebilirse - bilgi arkeolojisinden çok 'define avcılığına' benzetilebilir! Büyük ölçüde ABCFM belgeleriyle internet ortamından erişilebilen kaynaklardan derlenerek yayıma hazırlanan Anadolu'nun Kaybolan Renklerinden Bir Doğa Bilimci J.J. Manissadjian adlı kitap, ${ }^{3}$ hataları ve eksikleri nedeniyle, Prof. Ohannes Manisacıyan’ı bize layıkıyla tanıtamamaktadır.
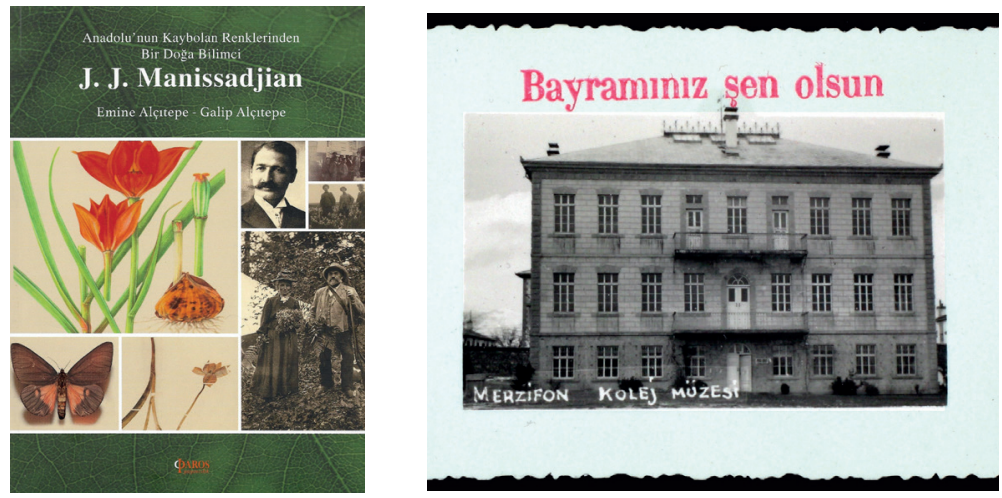

Merzifon Anadolu Koleji Müzesi (1933)

1919); İstanbul Boğaziçi Üniversitesi Kütüphanesi ABCFM Mikrofilm Arşivi; Digital Library for International Research (DLIR); SALT Araştırma (İstanbul); American Research Institute in Turkey (ARIT Istanbul); American Board of Commissioners for Foreign Missions (ABCFM) Near East, Records, 1820-1965, AndoverHarvard Theological Library, Harvard Divinity School (MA, ABD).

2 Gülbadi Alan, American Board'in Merzifon'daki Faaliyetleri ve Anadolu Koleji (Ankara: Türk Tarih Kurumu, 2008); Nil Sarı, "Merzifon Amerikan Misyoner Hastanesi," I. Amasya Araştırmaları Sempozyumu Bildirileri, 1315 Haziran 2007, Amasya. 1. kitap, ed. Yavuz Bayram (Amasya: Amasya Valiliği, 2007) içinde, 586-608; Ayşe Kökcü, “Osmanlı'da Astronomi ve Matematik Doktoralı İlk Bilim Adamımız: Arakel Garabed Sivasliyan,” OTAM (Ankara Üniversitesi Osmanlı Tarihi Araştırma ve Uygulama Merkezi Dergisi) sayı 38 (2015): 95-105; Ayşe Kökcü, "V. Hovhannes Hagopyan ve Avalim-i Felekiye eseri," Historia 1923 - Ermeni Sorunu sayı 2 (Güz 2016): 233246; Ayşe Kökcü, "Merzifon'da Bir Kadın Astronom: Charlotte Richards Willard," Kebikeç - Bilim Tarihi I sayı 47 (2019): 223-232; Meral Halifeoğlu, “Tarsus Amerikan Koleji’nin Kuruluşu, Gelişimi ve Faaliyetleri” (Yüksek Lisans Tezi, Fırat Üniversitesi, 2007); M. A. Galip Alçıtepe, Belgelerle Protestan Misyonerlerin Konya 'da Açtıkları Kurumlar ve Faaliyetleri (Konya: Çizgi Kitabevi, 2015); Scott M. Rank, "Centers of Provocation and Progress: Anatolian Missionary Stations within the Ottoman State and among Apostolic Armenians, 1878-1896" (Yüksek Lisans Tezi, İstanbul Bilgi Üniversitesi, 2009); Ayşe Aksu, "Amerikalı Misyonerleri Osmanlı Anadolu'sundaki Eğitim Faaliyetleri (1820-1900) ve Bunun Osmanlı Toplum Yapısına Etkileri” (Doktora Tezi, Marmara Üniversitesi, 2010); Gül Kızılca Yürür, “Gaziantep’teki Amerikan Hastanesi, Hastaneye Bağlı Tıp ve Sağlık Okullarının Tarihi ve Çevreye Etkileri” (Doktora Tezi, İstanbul Üniversitesi, 2013); Neşe Tozkoparan, “19. yy. Sonunda Sivas’ta Amerikan Protestan Misyoner Faaliyetleri” (Doktora Tezi, Ankara Üniversitesi, 2014); İdris Yücel, Anadolu'da Amerikan Misyonerliği ve Misyon Hastaneleri (1880-1934) (Ankara: Türk Tarih Kurumu, 2017); Faruk Taşkın, Amerikan Misyonerlerinin Türkiye'deki Sağllk Faaliyetleri, 1833-1923 (İstanbul: Kriter, 2019), vd.

3 Emine Alçıtepe ve Galip Alçıtepe, Anadolu'nun Kaybolan Renklerinden Bir Doğa Bilimci J.J. Manissadjian (İstanbul: Paros Yayıncılık, 2019), 18, 19.

4 "Merzifon Kolej Müzesi” 6.0x8.5 cm. SALT Araştırma, ABAHMRZ169.jpg. https://archives.saltresearch.org/ $\underline{\text { handle/123456789/45825 }}$ 
Kitabın kriptik başlığı ve "Bu toprakların yitik insanlarından J.J. Manissadjian'a" ithaf edilmiş olması, ${ }^{5}$ yazarların "elimizden yitip gitmiş bir bilim insanı" ve doğabilimciyi aradıklarını düşündürmektedir. Ermeni-Alman kökenli bir Osmanlı “vatandaş1" olan Ohannes Agop (Hovhannes Hagop) Manisacıyan, 7 1862'de, Sivas'ın Tokat kazasına bağlı Niksar'da başlayıp 1942'de ABD'nin Detroit kentinde biten 80 yıllık yaşamı, araştırma, gözlem ve buluşlarıyla bilim dünyasındaki yerini almıştır. ${ }^{8}$ Yazarlar, “elinizdeki kitabın özgün tarafı Anadolu'nun ilk Doğa Tarihi Müzesi’nin ortaya çıkarılmasıdır ki, bu müze Anatolia College'dadır"9 diyerek, Manisacıyan konusunda bilinenlerin kendilerini tarafından keşfedildiğini; bilinmeyenlerin ise kayıp olduğunu baştan ilan etmişlerdir. ${ }^{10}$

Yazarlar, Ohannes Agop Manisacıyan'ın adını, kitabın başlığında ve metin içinde "J.J. Manissadjian" olarak yazmayı seçerken bir açıklama yapmak gereğini duymamışlardır." Manisacıyan'ın kendisi, kullandığı üç dilli mühürde (1stampa) adını açıkça "Ohannes

5 Başlıktaki "kayıp" sözcüğü Merzifon ile ilgili başka yayınlarda da karşımıza çıkmaktadır: krş. Armen T. Marsoobian, Dildilyan Kardeşler: Kayıp Bir Ermeni Evinin Hatıraları. Anadolu'da Bir Ermeni Ailenin Fotoğraflart ve Öyküsü, 1888-1923 / Dildilian Brothers: Memories of a Lost Armenian Home. Photography and the Story of an Armenian Family in Anatolia 1888-1923, çev. Ahmet Fethi (İstanbul: Bir Zamanlar, 2015); Dildilian Kardeşlerin Objektifinden Bir Ermeni Ailesinin Yitik Geçmişine Tanıkliklar, 1872-1923, haz. Armen T. Marsoobian vd. (İstanbul: Anadolu Kültür, 2013); Armen T. Marsoobian, Fragments of a Lost Homeland: Remembering Armenia [Yitik Bir Yurdun Kirtnttlarl: Ermenistan'ı Hattrlamak] (London: I.B. Tauris, 2015); Dildilian Kardeşlerin Objektifinden Bir Ermeni Ailesinin Yitik Geçmişine Tanıklkklar, 1872-1923 (Sergi kitapçığı) http://www.depoistanbul.net/wp-content/uploads/2018/08/kitap_ince.TUR-1.pdf

Ayrıca, tümü iki koleksiyon arasında paylaştırıldığı halde "kayıp" sayılan bir Rumkale (Toros Roslin) yazmasının öyküsü için bkz. Heghnar Zeitlian Watenpaugh, The Missing Pages: The Modern Life of a Medieval Manuscript, from Genocide to Justice (Stanford, Ca: Stanford University Press, 2019).

6 Alçıtepe ve Alçıtepe, J.J. Manissadjian, 5, 13.

7 Ohannes Manisacıyan, 02.11.1926 tarihinde ABD uyruğuna geçerken John Jacob Manis adını almış; Manissadjian soyadını bırakmıştır, bkz. "John J. Manis, Armenian-born scientist and linguist dies in Detroit" (Nekroloji), The New York Times, Thursday, June 18, 1942, 21. Ayrica bkz., The American Philatelist 35 (5 Feb. 1922): 221 "Manissadjian, Prof. J.J., name has been officially changed (for convenience) to the following: Manis, Prof. J.J."

8 Alçıtepe ve Alçıtepe, J.J. Manissadjian, 18: “Manissadjian'ın bıraktığı bilimsel iz, hem 1915 trajedisi hem de Anatolia College'ın 1921'de kapanması nedeniyle, ne yazık ki, parça parça ve dağınıktır". Yazarlara göre, "ABD'ye yerleşmiş, hayata ve bilime küsmüş" olan (s. 13) Manisacıyan, 1933'te emekliye ayrılırken bu duygular içinde görünmemektedir: bkz. J.J. Manissajian, "Retiring after forty-three years of labor" (Kırküç yıl çalışmadan sonra emekli olurken), Missionary Herald, 129 (1933): 313-314. Manisacıyan bu yazısında soyadının İngilizce yazımını (Manissajian) kullanmıştır.

9 Alçıtepe ve Alçıtepe, J.J. Manissadjian, 96.

10 "Elinizdeki kitaba özgünlük kazandıran bir özellik de kaynakçasıdır" diyen yazarlar, (Alçıtepe ve Alçıtepe, J.J. Manissadjian, 19) kaynakçalarında Merzifon Anadolu Koleji Müzesini ve Prof. Manisacıyan’ı konu alan SALT Galata "Boş Alanlar" Sergisinin kitapçı̆̆ına (ed. Başak Çaka ve November Paynter, İstanbul, SALT Galata, 6 Nisan - 5 Haziran 2016) yer vermemişlerdir.

11 Yazarlar, Merzifon Amerikan Anadolu Koleji'nin "resmi" adının Anatolia College olduğunu belirterek, "Anadolu Koleji" biçiminde bir çeviriyi uygun görmediklerini açıklamışlardır (Alçıtepe ve Alçıtepe, J.J. Manissadjian, 18). Türkiye'de yerleşik bir kuruluşun resmi adının İngilizce olamayacağını söylemeye gerek yoktur. Resmi yayınlarda okulun adı “Anatolya Koleci” (آناطوليا قولجى) - günümüzdeki yazımla Anadolu Koleji - olarak geçmektedir: bkz. [Merzifon Anatolya Koleci, Merzifon,1330/1914, 18 s.] 
Manisacıyan" olarak yazmıştır. ${ }^{12}$ İsmin Batı Ermenicesiyle okunuşu ve yazılışı H.H. (Hovhannes Hagop) Manisaciyan'dır; “J.J. Manissadjian” yazımında önadlar “Johannes Jacob” Almancadır; Manissadjian/Manisadjian soyadı ise babası Barsam J. (Jacop/Agop?) “Ağa” tarafindan seçilen Fransızca transliterasyondur. (Barsam Manisacıyan'ın kullandı̆̆ Manissagian.) Ermenice isimlerde kural olarak: yazarların yabancı dillerdeki yayınlarında kullandıkları transliterasyon, yayın künyelerinde, bilimsel etiket ve epitetlerde, kaynakça ve kataloglarda aynen kullanılır; bunun dışında Ermenice ad/soyad yayının yapıldığı dilde geçerli olan yazım biçimini alır. ${ }^{13}$ Ohannes Manisacıyan adının Türkçe metin içinde "J.J. Manissadjian" olarak yazılmasını - Merzifon Anadolu Koleji ya da Anatolya Koleci yerine Anatolia College denilmesi, gibi - yersiz bir yabancılaştırma olarak görüyoruz. ${ }^{14}$

Bir biyolog (Emine Alçıtepe) ile bir tarihçi (M. Ali Galip Alçıtepe) tarafından kaleme alınan kitabın “Önsöz” ünün yazılışı $(06.12 .2017)^{15}$ ile yayımlanışı $(06.11 .2019)^{16}$ arasında yaklaşık iki yıl geçmiştir. Bu uzun sürede kitabın hazırlanışı bakımından bir boşluk vardır: geçen iki yılda metni okuyup inceleyen olmamış ve "J.J. Manissadjian'ın Biyografisisi" bölümünde (s. 54) Prof. Manisacıyan'ın yerine başka bir öğretmenin resminin konulduğunu fark edilmemiştir. ${ }^{17}$ Öte yandan, sanal ortamda "Manissadjian" adına ne varsa tarayan yazarlar, Manisacıyan'ın 1889 tarihli “Türkische Uebungen" (Türkçe Alıştırmaları) adlı kurs

12 Osman Köker, "Mavi Kitap’taki Merzifon kartpostalları," Virgül sayı 96 (Haziran 2006): 71-73. Krş. Alçıtepe ve Alçıtepe, J.J. Manissadjian, 217. Ayrıca, bkz. aşağıda dn. 104.

$13 \mathrm{Krş.} \mathrm{"When} \mathrm{authors} \mathrm{of} \mathrm{Armenian} \mathrm{origin} \mathrm{have} \mathrm{adopted} \mathrm{specific} \mathrm{transliterations} \mathrm{for} \mathrm{their} \mathrm{own} \mathrm{surnames} \mathrm{in}$ publications in foreign languages, we have generally retained the spelling they chose." Bkz. Alessandro Orengo ve Irene Tinti, "The Reception of Galen in the Armenian Tradition (Fifth-seventeenth Centuries)," in Brill's Companion to the Reception of Galen, eds. Petros Bouras-Vallianatos and Barbara Zipser (Leiden: Brill, 2019), 559 cf 2 .

14 Ermeni kökenli yazarlar da Türkçe yazılarında "Manissadjian" yerine Manisacıyan yazımını seçmişlerdir: bkz. Pars Tuğlacı (Parseh Tuğlaciyan), Tarih Boyunca Batı Ermenileri Tarihi, c. 3, 1891-1922 (İstanbul: Pars Yayın, 2004), 242, 507; Nazan Maksudyan, “Amerikan Kaynaklarında Merzifon Anadolu Koleji'nin Kısa Tarihçesi ve Boğos Piranyan,” Aşçının Kitabı: Merzifon Amerikan Anadolu Koleji Aşçısı, 1914 içinde (İstanbul: Aras Yayıncılık, 2008), 133-178; Nazan Maksudyan, “Amerikan Kaynaklarında Merzifon Anadolu Koleji’nin Kısa Tarihçesi,” Kebikeç say1 36 (2013): 131-153. Merzifon Anadolu Koleji’nde yapılan Rumca

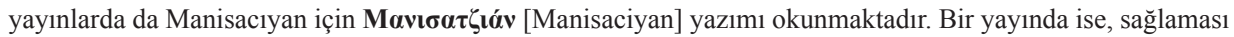
yapılmayan arşiv belgelerinden "Manajian" biçiminde yanlış transliterasyon vardır, bkz. Emrah Şahin, Faithful Encounters: Authorities and American Missionaries in the Ottoman Empire. (Montreal and Kingston, McGillQueen's University Press, 2018) 128.

15 Alçıtepe ve Alçıtepe, J.J. Manissadjian, 13 “Önsöz” (06.12.2017).

16 Galip Alçıtepe, "Açık Davetiye" (Twitter, 26.09.2019): "Eşim Doç.Dr. Emine Alçıtepe ile birlikte kaleme aldığımız kitabımızın tanıtım toplantısı 06.11.2019 tarihinde..."

17 Dildilyan albümünde, "Birinci Dünya Savaşı başlamadan önce Anadolu Koleji öğretim üyelerinin son fotoğrafi, 1914 civarı" altyazılı grup fotoğrafında Prof. Ohannes Manisacıyan, ikinci sırada sağ baştaki Prof. Dimitrios Theoharidis'in yanındaki kişidir. https://archives.saltresearch.org/handle/123456789/45824 Alçıtepe ve Alçıtepe tarafından “J.J. Manissadjian” (s. 54) olarak gösterilen kişi, aynı resimde Manisacıyan'ın önünde oturan, okulun Rum öğretmenlerinden Konstantinos Yuannis Konstantinidis'dir (Constantinos Ioannis Constantinides). K. Konstantinidis (Sungurlu, Çorum doğumlu, B.A. Anadolu Koleji 1906, M.A. Grinnell College, ABD 1912), 1915-1916 ders yılına ait, Manisacıyan ve diğer Ermeni öğretmenlerin yer almadığı bir grup fotoğrafında görülmektedir (SALT Araştırma ABAHPRT196). 
kitabının tıpkıbasımını içeren ${ }^{18}$ ve onun Almanya'daki dilbilim çalışmalarını konu alan tek makaleyi görememişlerdir. ${ }^{19} \mathrm{Bu}$ makalenin kaynaklarından biri özellikle dikkate değerdir, çünkü Ohannes Manisacıyan için verilen bir referansta "anadilinin Türkçe, Almancasının mükemmel" olduğu belirtilmiştir. ${ }^{20}$

Yazarlar, girişte "Osmanlı coğrafyasındaki ilk doğa tarihi müzesi”nin kuruluş tarihini 1871 ve kurucusunu Dr. Macarlı Abdullah Bey olarak yanlış vermiş; müzenin Mekteb-i Tıbbiye-i Askeriye-i Şahane içinde yer aldığını belirtirken, yerini "bugünkü Marmara Üniversitesi Haydarpaşa kampüsü” olarak yine yanlış göstermişlerdir. ${ }^{21}$ Galatasaray' daki Askeri Tibbiye'nin yangınla yok olduğu tarihe (11 Ekim 1848) dikkat edilmiş olsaydı bu hatalara düşülmezdi. ${ }^{22}$

Benzer bir hata, Anadolu Koleji Doğa Tarihi Müzesi’nin, okulun erkek kısmıyla birlikte 1921'de kapandığı varsayımıdır. ${ }^{23}$ Anadolu Koleji'nin kız okulu, 8 Ocak 1924 tarihinde "Merzifon Amerikan Kız Hayat Mektebi” olarak yeniden öğretime açılmıştır; ${ }^{24}$ Müze ise kapanmamıştır. 1929 tarihli bir teftiş raporunda Müze'nin yöredeki öğrencilere ve halka açık olduğu, eğitim amacıyla kullanıldığı belirtilmektedir: "Kütüphanesi olmağla beraber müesseseye ait muntazam ve çok zengin bir de müzesi vardır. Bu müze bütün memleket halkına da açık bulundurulmaktadır. Zaman zaman mekteplerimiz de bu müzeden istifade

18 Sebastian Cwiklinski, “'Türkische Uebungen für den Anfänger-Cursus': ein Lehrbuch aus dem Jahre 1889,” Archivum Ottomanicum, 22 (2004): 107-124.

19 Manisacıyan bu Türkçe kitabını, yazarların Berlin Friedrich Wilhelm Üniversitesi kataloğundan (Verzeichnis der Vorlesungen welche auf der Friedrich-Wilhelms-Universität zu Berlin inm Winters-Semester vom 16. October 1889 bis 15 März 1990 gehalten werden) aktararak “Türkçe konuşma egzersizleri” olarak çevirdikleri "Türkische Übungen (Anfängercursus)" derslerinde kullanmıştır. https://www.digi-hub.de/viewer/image/ DE-11-001790311/34/LOG_0019/Manisacıyan'ın Berlin'den döndükten sonra yayımladığı Mürşid-i Lisan-i Osmani / Lehrbuch der modernen osmanischen Sprache (Stuttgart, W. Spemann-Vlg., 1893) adlı kitabı üzerine bir makale hazırlayan Çiğdem Yıldırım'ın da yayından habersiz olduğunu belirtmemiz gerekir, bkz. H. Çiğdem Yıldırım, "19. Yüzyılda Almanlara Türkçe Öğretmek Amacıyla Yazılmış Bir Kitap: Mürşid-i Lisan-ı Osmani," Başkent University Journal of Education, 4, 1 (2017): 74-83. Mürşid-i Lisan-i Osmani'nin 1902 y1lında yapılmış bir ikinci basımı yoktur; 2017'de tıpkıbasımı yapılmıştır (Norderstedt, Hansebooks).

20 [Friedrich Carl Andreas] "Als Argument wurde angeführt, daß Türkisch seine [Manissadjians] Muttersprache sei, er das Deutsche perfekt beherrsche..." Cwiklinski, "Türkische Uebungen," 109, dn. 12. Manisaciyan'ın anadilinin Almanca, "babadilinin” Türkçe olduğunu söylemek daha doğru olur. Manisacıyan, mühürüne adını Türkçe-Ermenice-Almanca olarak üç-dilli yazdırmasının nedeni her üç dili de anadili gibi kullanabilmesi; diğer bir deyişle, kendisini “üç kültürlü” bilmesindendir. Manisacıyan, 1925'de Amerika'da yayımladığı bir kitapçığa da Proverbs from Turkey (Türkiye’den Atasözleri) adını vermiştir. Ayrıca, bkz. aşağıda dn. 85.

21 Alçıtepe ve Alçıtepe, J.J. Manissadjian, 17. Kitabın yayımlandı̆̆ı tarihte: Sağlık Bilimleri Üniversitesi Haydarpaşa yerleşkesi.

22 Feza Günergun, “Ondokuzuncu yüzyıl İstanbul’unda İki Doğa Tarihi Müzesi: Mekteb-i Tıbbiye-i Şahane ve Darüşşafaka Koleksiyonları,” Toplumsal Tarih sayı 311 (Kasım 2019): 48-54.

23 Alçıtepe ve Alçıtepe, J.J. Manissadjian, 33.

24 Öğrenciler, okullarının özellikleri arasında Doğa Tarihi Müzesini sayarlar: "Our school for girls is to be found on large grounds formerly occupied by a 'Kollej'. The Girls' School garden and trees, a natural history museum and a playground are among the attractions of the property." The Merzifonian, (published by the advanced English classes of the Merzifon American School) No. 5, 1936, 4. 
etmektedir". ${ }^{25}$ Müze, Merzifon Amerikan Okulu'nun kapandığı 1939 yılına kadar açık kalacaktır.

Yazarlara göre, Manisacıyan, "İnanmış bir Protestan - Pozitivist bir bilim insanı - Politik açıdan bir Ermeni milliyetçisi” ve "Tipik bir 'Aydınlanma Devrimi' entellektüeli"dir. ${ }^{26}$ Bağdaştırılması zor bu dört niteliğin Manisacıyan’ın kişiliğinde nasıl buluştuğu anlaşılamamakla birlikte, ${ }^{27}$ bir konuda internetten devşirilen cümleler dizilip düzülerek herhangi bir sonuca varılabilir. Birinci bölümün başındaki bu iliştirmelerin kitabın (olmayan) değerlendirme ve sonuç bölümünde ele alınıp ayrıca tartışılması gerekirdi.

Bir yüksek lisans tezinde "Manissadjian'ın bir Alman botanikçi olarak gösteril[mesini]"28 eleştiren yazarlara göre, Manisacıyan "Ermeni kökenlidir", (s. 18) ama "yarı Alman” (s. 65) olduğu için de 1915 'te Anadolu Koleji’nin diğer Ermeni öğretmenlerinden ayrılarak Göynük, Amasya' daki Alman kolonisinin çiftliğine gidebilecektir. ${ }^{29}$ "Manissadjian, bilimsel başarılarına karşın hükümetle hep sorunlar yaşamıştır. Bunun en önemli nedeni kuşkusuz, Ermeni milliyetçisi olmasıdır" savı, ${ }^{30} 1917$ 'de Merzifon'a dönerek savaşın sonuna kadar ordunun denetimindeki Anadolu Koleji’nde yaşayan Prof. Manisacıyan için tutarlı

25 Remzi Bey (İlköğretim Müfettişi), Harf İnklabının İlk Yıllarında Bir Teftiş Raporu (1928-1929 Eğitim-Öğretim Y1lı Amasya İli Merzifon ve Gümüşhacıköy Eğitim Bölgesi Genel Teftiş Raporu), yay.haz. Mustafa Kılınç, Metin Orbay (Ankara: Pegem Akademi Yayıncılık, 2018), 128. "Merzifon Amerikan Mektebi, 5-Kütüphane, Müze". Ayrıca, bkz. Mustafa Kılınç, Metin Orbay, "İlköğretim Müfettişi Remzi Bey’in Teftiş Raporunda 'Merzifon Amerikan Okulu'," Amasya Üniversitesi Sosyal Bilimler Dergisi 2, 4 (Aralık 2018): 103-129.

26 Alçıtepe ve Alçıtepe, J.J. Manissadjian, 53, 61.

27 Alçıtepe ve Alçıtepe, J.J. Manissadjian, 63. Argotis homicida adının açıklaması için bkz. Otto Staudinger, "Neue Lepidopteren des palaearktischen Faunengebiets," Deutsche Entomologische Zeitschrift Iris 12 (1899): 363.

28 Alçıtepe ve Alçıtepe, J.J. Manissadjian, 17. Değinilen tezin yazarı Ebru Akdeniz değil, Ebru Özdeniz'dir. Tezde Manisacıyan adı "Manisadjian” olarak yazılmıştır. Yazarın, "Çıplak 1997” olarak verdiği kaynağın tam künyesi için, bkz. Tuna Ekim, "Ülkemizdeki Floristik Çalışmaların Kronolojisi ve Son Gelişmeler,” Taksonomi Yaz Okulu Ders Notlarl, 7-13 Eylül 1997, Akdeniz Üniversitesi / O.D.T.Ü, Antalya, ed. Battal Çıplak içinde (Antalya: [kişisel yayın], Eylül 1997), 51-72.

29 Ohannes Manisacıyan ile Arşak Dağlıyan, aileleriyle birlikte Amasya'daki Alman kolonisine katılmışlardır: "Prof. Manissadjian, Prof. Daghlian, and their families went to the German settlement at Ata Bey, July 3rd [1915]," (George E. White ?) ABD Büyükelçisi Henry Morgenthau'ya yazılmış 2 Ekim 1915 tarihli mektup. https://archives.saltresearch.org/handle/123456789/44008 Atabey Alman çiftliği için bkz., Hadi Belge, "Alman kolonyal politikaları ve Protestan misyonerliği için bir örnek: Amasya Atabey Çiftliği (1879-1919)," History Studies 10, 8 (Kasim 2018): 49-75.

30 Alçıtepe ve Alçıtepe, J.J. Manissadjian, 63. 
görünmemektedir. ${ }^{31}$ Ohannes ve Arusyag (Eunice) Manisacıyan ${ }^{32}$ çiftinin altı çocuğunun Alman isimleri taşımasının üzerinde de durulmamıştır. ${ }^{33}$

Biyografide yer almayan detaylara göre, Prof. Ohannes Manisaciyan, Merzifon Anadolu Koleji'nde 1910 Ocak ayında Ermenice olarak yayımlanmaya başlanan Nor

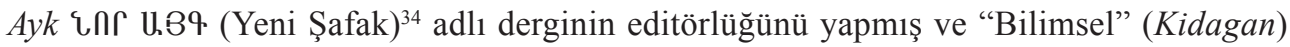
bölümüne makaleler yazmıştır. ${ }^{35}$ Manisacıyan 1910 yılında izinlidir ve önce Avusturya üzerinden Almanya'ya gidecektir. ${ }^{36}$ Merzifon Anadolu Koleji Müzesi'ne ait bir etiketten, ${ }^{37}$ Manisacıyan'ın daha sonra İsviçre'de olduğunu ve Grindelwald yakınlarındaki “Eiger Buzulu üzerindeki moren yüzeyinden” 28 Ağustos 1910 tarihinde bir taş örneği aldığını öğreniyoruz. Manisacıyan, 1912 yılının ikinci döneminde de Amerikan Kız Koleji'nde kimya, biyoloji ve fizyoloji derslerini vermek üzere İstanbul'a gidecektir. ${ }^{38}$ Manisaciyan, İstanbul'da bulunduğu sırada, daha önce Merzifon'a gelmiş olan bitki toplayıcısı Kevork Vensan Aznavur ile görüşmüş olmalıdır. ${ }^{39}$

31 Anadolu Koleji, 10 Mayıs 1916 ile 2 Nisan 1919 tarihleri arasında askeri birliklerin denetiminde kalmıştır. Merzifon'daki Anadolu Koleji’nin bütün malvarlığı, 5 Temmuz 1916 tarihinde, D. K. Getchell imzalı bir tutanakla belirlenmiştir: bkz. Alçıtepe ve Alçıtepe, J.J. Manissadjian, 85. Bu belgede Müzenin koleksiyonunun (no. 20. Specimens in Museum) değeri 1.000 Lira (Ltq) olarak kabul edilmiştir. İlginç olan, belgede okulun beş profesörünün evi sayıldığı halde Manisacıyan'ın evi yoktur.

32 Ohannes Manisacıyan'ın eşi Arusyag Manisacıyan, Anadolu Koleji'nin müzik öğretmeni Arşak Dağlıyan'ın kızkardeşidir; annelerinin Alman olduğu anlaşılmaktadır: "Professors [Manissadjian] and [Daghlian], both of whose mothers are Germans, from the German colony of [Atabey] near [Amasia]..." James Bryse, Arnold Toynbee, The Treatment of Armenians in the Ottoman Empire, 1915-1916, Documents Presented to Viscount Grey of Falloden by Viscount Bryce, ed. Ara Sarafian (Princeton NJ: Gomidas Institute, 2000), 368.

33 Alçıtepe ve Alçıtepe, J.J. Manissadjian, 55-56. Armin, Otto, Wilhelm, Katherine, ve Edward Merzifon'da, Lily Maria ise 12.05.1889'da Berlin'de doğmuştur. Üçüncü çocukları Otto Heinrich Barsam Manisacıyan, Merzifon'da ölmüştür.

34 Anadolu Koleji'nin “The Morning Cometh" (Gün doğuyor) mottosundan esinlenen bir başlıktır.

35 Derginin başlığındaki Türkçe açıklama: Nor Ayk, Siyasi, İlmi, Edebi ve Fenni Ermenice Aylık Risale. Sahib-i imtiyaz ve Müdir-i mesulü: Keyork (Keğork) Gülyan, Merzifon'da Anatolya Koleci. Nor Ayk dergisinin incelediğimiz 37 sayısı içinde Manisacıyan'ın 13 yazısı vardır. http://tert.nla.am/mamul/Nor\%20Ayg\%20 Marz/Table.html. Ayrica bkz., Krikor Damadyan (Kidemli Peder), "Prof. J.J. Manissadjian ve Nor Ayk Dergisi," Paros say1 100 (Ocak 2020): 114-116.

36 The Anatolian, 1911-1912, Marsovan, Turkey [yy.], 34-35. Manisaciyan dönüşünde "Impressions of Europe After Twenty Years" (10 Mart 1911, Yirmi Yılın Ardından Avrupa İzlenimleri) başlıklı bir konferans vermiştir: bkz. The Anatolian, 1911-1912, Marsovan, Turkey [yy.], 28. Bu sunum, yazarların ileri sürdükleri gibi, bir "Biyoloji Konferansı" değildir, Alçıtepe ve Alçıtepe, J.J. Manissadjian, 43.

37 Alçıtepe ve Alçıtepe, J.J. Manissadjian, 80. Etiketin web adresinde bu görsel için “Anadolu Koleji Müzesi koleksiyonundan bir numunenin etiketi” açıklamasının yanında, fotoğrafın Tarsus Amerikan Koleji'nde çekildiği (C) Sağlık Eğitim Vakfı (SEV) kaydı vardır: https://commons.wikimedia.org/wiki/File:Specimen label from the collection of Anatolia College Museum.jpg

38 American College for Girls at Constantinople, President's Report, 1912-1913 ([İstanbul], 1912), 27.

39 Asuman Baytop, “J.V. Aznavur (1861-1920), İstanbul Bitkileri Koleksiyonu ve Yayınları,” Osmanlı Bilimi Araștırmalart 13, 2 (2012): 31-40. 


\section{Araştırılmayan ve incelenmeyen birincil kaynaklar}

Kitabın temel sorunu ise kaynaklarıyla ilgilidir:

(i) Ankara Üniversitesi Fen Fakültesi Herbayumu Herbarium Turcicum (ANK) içindeki Manisacıyan koleksiyonu incelenmemiştir. Kitabın son bölümünde "çalışma yapılan herbaryumlar" arasında gösterilmesine karşın, Herbarium Turcicum içindeki Manisacıyan (J.J. Manissadjian) koleksiyonunun örnekleri sayılmamıştır. ${ }^{40}$ Kitapta ANK koleksiyonunun neden incelenmediğine ilişkin bir açıklama yoktur.

(ii) Merzifon'dan Tarsus Amerikan Koleji'ne gelen Anadolu Koleji doğa tarihi koleksiyonu görülmemiştir. Koleksiyon bugün, okula ait tarihi Sadık Paşa Konağı içinde, Doğa Bilimleri Araştırma Merkezi'ndeki yerini almıştır. ${ }^{41}$ İstanbul'da SALT Galata'da 6 Nisan 2016 tarihinde açılan "Boş Alanlar" sergisinin hazırlıkları sırasında, sergi küratörleri Tarsus’a giderek koleksiyonu yerinde incelemişlerdir. ${ }^{42}$ Kitabın yazarları, Anadolu Koleji'ndeki "Müzeden Tarsus Amerikan Koleji'ndeki bir kaç parça örnek dışında bir şey kalmamıştır” inancında oldukları için, ${ }^{43}$ ilgililerden örnek sayısının "binler” düzeyinde olduğunu öğrendikleri halde, 12 Mayıs 2018 tarihinden beri sergilenmekte olan koleksiyonu incelemeye gerek görmemişlerdir. ${ }^{44}$

(iii) Yazarlar, Manisacıyan'ın 1902'de İstanbul'da yayımlanan Ermenice Büyük Resimli Coğrafya ders kitabının adını duymamışlardır. ${ }^{45}$ Coğrafya, Anadolu Koleji’nde önem verilen derslerden biri olarak öne çıkmaktadır ve okulun rehberlerinde giriş koşulları arasında dil

40 Alçıtepe ve Alçıtepe, J.J. Manissadjian, 173, 187. Kitapta bu koleksiyon hakkında verilen tek bilgi şudur: “Ankara Üniversitesi Fen Fakültesi Herbaryumu'nda 'Boş Alanlar' sergisi kataloğunda yer verilen bilgiye göre, biri tip örneği (Silene manissadjiani) olmak üzere 130 bitki örneği bulunmaktadır.” (s. 186).

41 BizLetter, TAC Alumni BizLetter Alma Matter (Tarsus Amerikan Koleji Mezunlar Derneği) 4 (2017): 25-29. https://tac-alumni.org/wp-content/uploads/5a141de94639c.pdf BizLetter, 2 (2019): 48-51 https://tac-alumni. org/wp-content/uploads/5d0753c66e341.pdf. Anadolu Koleji koleksiyonu üzerindeki son çalışmalar için, bkz. Gönenç Göçmengil, “Merzifon Anadolu Koleji Müzesi’nin Tarihsel Gelişimi,” Toplumsal Tarih sayı 311 (Kasim 2019): 64-70.

42 Bkz. Boş Alanlar (SALT Galata Sergi kitapçı̆̆ı, küratör: Marianna Hovhannisyan), 36-40. https://saltonline.org/media/files/bos-alanlar_sergi-brosuru-1.pdf

43 Alçıtepe ve Alçıtepe, J.J. Manissadijian, 17.

44 Gönenç Göçmengil, Şeref Etker, Semih Bilgin, Nihat Taner, "Tarsus Amerikan Koleji Doğa Bilimleri Araştırma Merkezi Koleksiyonunun Tarihsel Oluşumu ve Geleceği," Ulusal Botanik Bahçeleri, Arboretumlar, Herbaryumlar Çalıştayı Bildiri Özetleri Kitabl, Düzce Üniversitesi Orman Fakültesi, DUOF Herbaryumu, Düzce, 18 -21 Nisan 2019, 57. http://ubahcalistayi.duzce.edu.tr/Dokumanlar/ubahcalistayi/Dosyalar/ozet kitapcik.pdf. Gönenç Göçmengil, Şeref Etker, Semih Bilgin, Nihat Taner, "The Evolution of an Anatolian Natural History Museum: from Merzifon to Tarsus, 1886-2019" (Sözlü bildiri) 2nd International NEHT (Network for the Study of Environmental History of Turkey) Workshop, Historicizing Nature: Water, Forest and Land. Environmental Histories of the Ottoman Empire and Turkey, Ankara ODTÜ, 6-7 September 2019. https://www.youtube.com/watch?v=J1hq21UIB1k

45 Alçıtepe ve Alçıtepe, J.J. Manissadijian, 45. Yazarlar, Catalogue of the St. Paul's Institute, Tarsus, Asia Minor, seventeenth year, 1887-1904 (Beirut: American Press, [1904]) adlı kitaptaki bilgiden St. Paul Enstitüsü'nde "Ermenice verilen coğrafya derslerinde Manissadjian'ın kaleme aldığı ders notlarının okutulduğu" sonucunu çıkarmışlar, bunun Manisacıyan'ın, Pars Tuğlacı'nın sözünü ettiği coğrafya kitabı olduğunu anlamamışlardır, bkz. Pars Tuğlacı, Tarih Boyunca Batı Ermenileri Tarihi, c. 3, 242. 
(anadil ve Türkçe okuyup yazma) yeterliği yanında, coğrafya ve aritmetik işlemler (hesap muamelatı) bilgisi sayılmıştır. ${ }^{46}$

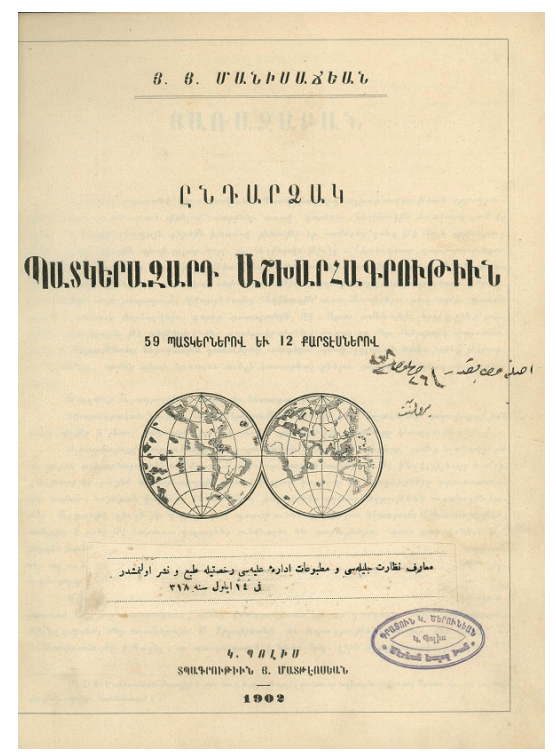

H.H. [Hovhannes Hagop] Manisaciyan Intartsag Badgerazart Aşkharakrutyun [Büyük Resimli Coğrafya] İstanbul, 1902 ${ }^{47}$
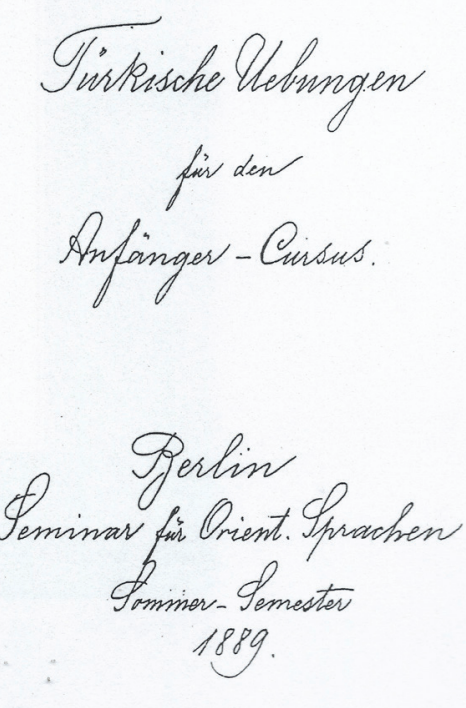

[Johannes Jacob Manissadjian]

Türkische Uebungen für den Anfänger - Cursus Berlin, Seminar für Orientalische Sprachen, $1889^{48}$

(iv) Manisacıyan'ın Almanya'da aldığı doğa bilimleri eğitimi araştırılmamıştır. ABCFM arşivindeki bir belgeye dayanılarak Manisacıyan'ın “Berlin Üniversitesi'nde... fen bilimleri üzerine master yap[tı̆̆ı]" yazılmış, ancak bu bilgi doğrulanmamıştır. ${ }^{49}$ Ohannes Manisacıyan, Antep'teki Orta Türkiye (Central Turkey) Koleji’nden B.A. derecesini

46 "Şerait-i duhuliye: Kendi ana lisanından ve Türkceden düzgünce okuyub yazmayı bilmeli ve coğrafya ile hesabdan az çok muamelatı olmalı." [Merzifon Anatolya Koleci] [1]330/1914], 4.

47 H. H. [Hovhannes Hagop] Manisaciyan Intartsag Badgerazart Aşkharakrutyun [Büyük Resimli Coğrafya] 59 Badgernov yev 12 Kardesnerov, G. Bolis, Dbakrutyun H. Madteosyan [İstanbul: Hagop Madteosyan Matbaas1] 1902, $18.5 \times 24 \quad \mathrm{~cm}$, xiii +174 s. (dizin, 59 şekil, 8 tablo)+12 s. harita. (Maarif Nezaret-i celilesi ve Matbuat İdare-i aliyesi ruhsatile tab ve neşrolunmuştur fi 4 Eylül sene 1318 [17 Eylül 1902]). Kitabı incelememize yardımcı olan sayın Tomas Terziyan’a teşekkür ederiz. 48 Cwiklinski, "Türkische Uebungen," 115.

49 Alçıtepe ve Alçıtepe, J.J. Manissadijian, 56. ABCFM Archive, ABA ASR00031303. 
aldıktan sonra, ${ }^{50}$ üç yıl ilkokul öğretmenliği yapmış, ${ }^{51}$ ardından Almanya’ya giderek 188687 Kış döneminde Heidelberg Üniversitesi’nde doğabilimi (Naturwissenschaft) öğrenimine başlamıştır. ${ }^{52}$ Ohannes Manisacıyan 1887 Yaz döneminde Berlin'e giderek "Fakultät für Naturwissenschaften der Königlichen Friedrich-Wilhelms-Universität” öğrencisi olmuştur. ${ }^{53}$ Doğabilimi eğitimini 1888-1889 Kış dönemi sonunda tamamlayan Manisacıyan, iki y1l da (Ekim 1888-Ağustos 1890) Üniversite'nin “Das Seminar für Orientalische Sprachen" bölümünde Türkçe okutmanlığı (Lektor) yapmıştır. Almanya dönüşünde, 1890'da Anadolu Koleji'ne öğretim kadrosuna alınan Ohannes Manisacıyan'ın akademik unvanı A.B. (Artium Baccalaureatus) olarak gösterilmiştir.

(v) Manisaciyan'ın değinilen, Londra Doğa Tarihi Müzesi'ndeki ve diğerkurum ve kuruluşlarda bulunan yazışmaları değerlendirilmemiştir. ${ }^{54}$ Manisacıyan'ın hazırladığı Anadolu Koleji Müzesi Kataloğunun ${ }^{55}$ başkakopyalarılopolmadığı bilinmemektedir. Manisacıyan,Lepidoptera(kelebek) ve bitkiler (botanik) için ayrı kataloglar hazırladığını ve bunların Müze'deki “M vitrininin üst çekmecesinde" olduğunu yazmıştır (Katalog, s. 155).

50 General Catalogue of Central College, Aintab, Turkey, Asia- (Beirut: American Press, 1906), 54. Class of 1883 (Arts) Hovhannes Manissajian. (Okul kataloğunda Manisacıyan adının bir İngilizce transliterasyonu: Manissajian kullanılmıştır.) Anadolu Koleji de mezunlarına B.A. (Bachelor in Arts) derecesi vermektedir: bkz. [Merzifon Anatolya Koleci, 1330/1914], 6. “Anatolya Koleci kendi müdavimlerine idadi ve sultani (yani kolec) dairelerini ikmal edenleri ve atideki derslerden imtihan geçirmeye muvaffak oldukları halde, Edebiyat İcazetnamesine muadil bakalorya (B.A.) diploması tefviz eder."

51 Prof Manisacıyan, 1922 Haziranında ABD'de Chippewa Falls, WI kentinde yaptığı bir konuşmada özgeçmişi, öğrenciliği ve öğretmenliği hakkında bilgiler vermiştir: "Prof. [John Jacob] Manis, in opening his talk gave a sketch of personal history which was interesting: He was born in Asia Minor. His father was a Congregational pastor, Armenian. His mother was German. He graduated from the American [Central Turkey] College at Aintab, Syria, taught three years in a grammar school in his home town [Merzifon] Amassia, then studied four years in Heidelberg and Berlin, Germany, and returned to Marsovan, Asia Minor, where at Anatolia College, a foundational of the American Congregational Board, he taught for twenty-five years," Chippewa Daily Gazette, June 7, 1922, 1. https:/www.newspapers.com/clip/20344338/

52 Die Matrikel der Universität Heidelberg 1386-1920 - digital, 408-409. Johannes Manissadjian (24 yaşında, Niksar, Türkiye doğumlu, Protestan) 21 Ekim 1886 tarihinde, 53 sira numarası ile Heidelberg Üniversitesi'ne "Naturwissenschaft" öğrenimi için kayı olmuş ve 20 Fl. (Gulden) ödemiştir, bkz. https://digi.ub.uni-heidelberg.de/diglit/uah_m12/0820

53 Cwiklinski, "Türkische Uebungen," 109. Ayrıca bkz. Amtliches Verzeichnis des Personals und der Studierenden der königlichen Friedrich-Wilhelms-Universität in Berlin auf das Sommerhalbjahr 16. April bis 15. August 1887 (Berlin, Gustav Schade, 1887), 88; Amtliches Verzeichnis des Personals und der Studierenden der königlichen Friedrich-Wilhelms-Universität in Berlin auf das Winterhalbjahr 16. Oktober bis 15. März 1889 (Berlin, Gustav Schade, 1887), 103. Böylece Ohannes Manisacıyan, Heidelberg Üniversitesi'nde bir dönem ve Berlin Friedrich Wilhelm Üniversitesi'nde dört dönem doğabilimi öğrenimi görmüş olmaktadır. Manisacıyan, Almanya'da dört yıl eğitim aldığını söylemektedir, bkz. yukarıda dn. 51 .

54 Alçıtepe ve Alçıtepe, J.J. Manissadjian, 20. Bu bilimsel yazışmalara, incelenmemiş olan 1922'de Almanya'ya yaptığı gezinin raporu da katılabilir: bkz. Alçıtepe ve Alçıtepe, J.J. Manissadjian, 68.

55 Museum Catalogue as came from Merzifon, 1939 https://archives.saltresearch.org/handle/123456789/42920 . Bundan sonra "Müze Kataloğu” olarak anılacaktır. 
(vi) Ohannes Manisacıyan'ın geniş bir ailesi vardır. ${ }^{56}$ Ailenin ABD ve İngiltere'de yaşayan bireyleri ile iletişime geçilmeye çalışıldığına dair bir bilgi yoktur.

(vii) Kitap 2019 Kasımında yayımlandığı halde, son iki yıla ait yayınlar kullanılmamıştır. Bunların arasında yazarların iki bildirisi de vardır. ${ }^{57}$ Aynı dönemde Merzifon Anadolu Koleji’ni mimarlık tarihi açısından ele alan iki yüksek lisans tezi tamamlanmıştır:

Büşra Saatci. Merzifon Amerikan Board Misyoner Yerleşkesinde Yer Alan Yapıların Değisşim Analiz ve Değerlendirmesi. Yüksek Lisans Tezi, Eskişehir Teknik Üniversitesi, Mimarlık Anabilim Dalı, Fen Bilimleri Enstitüsü, Nisan 2019. (xiv+111+3 s., 66 tablo, 57 şekil). Danışman: Doç. Dr. Hicran Hanım Halaç.

Aslı Kırbaş. Geç Osmanlı Döneminde Bir Misyoner Yerleşkesi: Merzifon Amerikan Koleji. Yüksek Lisans Tezi, İstanbul Teknik Üniversitesi Fen Bilimleri Enstitüsü, Mimarlık Anabilim Dalı Mimarlık Tarihi Bilim Dalı, Haziran 2019. (179 s., 121 şekil). Danışman: Doç.Dr. Vesile Gül Cephanecigil.

Kitapta, Müze binasının tamamlanmış halini gösteren bir resime yer verilmemiştir. ${ }^{58}$ "Herbaryumun da içinde olduğu müze, amfiteatr tarzında yapılmıştır" cümlesi yanlış bir çeviridir; gösterilen kaynakta herbaryum sözü geçmemektedir. ${ }^{59}$ Kitapta "Anatolia College botanik bahçesi" olarak gösterilen bir resim (s. 41, sol alt) arşivlerde "Kolej çiçek bahçesi" dir. ${ }^{60}$ Çiçekliğin bir botanik bahçesi düzeninde olmadığı fotoğraftan kolayca anlaşılabilmektedir. Kitapta Manisacıyan, "ayrıca bir okul içinde botanik bahçesi kurmuştur"61 denilmekte

56 İnternetteki soyağacı (jeneoloji) sitelerini kullanan yazarların Ohannes Manisacıyan’ın yaşayan aile bireylerini görmüş olmaları gerekir, bkz. Alçıtepe ve Alçıtepe, J.J. Manissadijian, 216. Ohannes Manisacıyan'ın çocuklarından Wilhelm, Edward ve Katherine ABD’ne, Armin ve Lily Maria İngiltere'ye yerleşmiştir.

57 Emine Alçıtepe ve Galip Alçıtepe, "II. Abdülhamid Devrinde Botanik Eğitimi," Vefatının 100. Yılında Sultan II. Abdülhamid ve Dönemi Uluslararası Kongresi Bildiri Özetleri, İstanbul, 22-24 Ekim 2018 (y.y.), 280. "Ülkemizin değişik yerlerinde kurulan Amerikan kolejleri ve diğer yabancı ve azınlık okulları da bu kapsamdadır. Bu bağlamda, İstanbul, Erzurum, Antep, Tarsus ve Merzifon'da herbaryumlar kurulmuştur.” Emine Alçıtepe ve Galip Alçıtepe, “Anadolu’nun Kayıp Herbaryum ve Botanik Bahçeleri (1879-1915),” Ulusal Botanik Bahçeleri, Arboretumlar, Herbaryumlar Çalıştayı Bildiri Özetleri Kitabı, Düzce Üniversitesi Orman Fakültesi, DUOF Herbaryumu, Düzce, 18-21 Nisan 2019, 45. http://ubahcalistayi.duzce.edu.tr/Dokumanlar/ ubahcalistayi/Dosyalar/ozet kitapcik.pdf

58 Müze binasının yanmış halini gösteren fotoğrafın bulunduğu sayfada "Manissadjian müzesinin bulunduğu ikinci kat yok olmuştur” ifadesi bulunmaktadır: bkz. Alçıtepe ve Alçıtepe, J.J. Manissadijian, 33. Halbuki Anadolu Koleji Doğa Tarihi Müzesi, binanın üçüncü katındadır.

59 Charles C. Tracy, "The New Library-Museum at Anatolia College,” The Orient, vol. IV, no. 43, October 22, 1913, s.1'den aktaran Alçıtepe ve Alçıtepe, J.J. Manissadijian, 84. Tracy'nin yazısında üçüncü katta müze, amfitiyatro biçiminde bir doğa bilimleri dersliği ve küratöre ait iki oda olduğu yazılıdır: "On the third floor is the museum, a Natural Science class room in amphitheatre style, and two Curator's rooms." Burada ayrı bir herbayumundan söz edilmemiştir. http://www.dlir.org/archive/orc-exhibit/items/show/collection/9/id/12255. Bir başka kaynakta "Natural science classroom with curator's laboratory" (Küratörün laboratuarı ile doğa bilimleri dersliği) ifadesi vardır: bkz. The Anatolian, 1913-14, s. 15, http://www.dlir.org/archive/orc-exhibit/ items/show/collection/6/id/11079

60 "College flower garden" https://archives.saltresearch.org/handle/123456789/44809 ABAHACMRZ024.jpg; Anatolia College Merzifoun, (Albüm. у.у.) [H.B.] Manissadjian and Co., Basel-Zurich, [s. 26] https://archives. saltresearch.org/handle/123456789/45805 ABAHMRZ093.jpg

61 Alçıtepe ve Alçıtepe, J.J. Manissadijian, 41. 
ise de, Anadolu Koleji'nin planında bir botanik bahçesi gösterilmemiştir. ${ }^{62}$ Keza, "J.J. Manissadjian, öğrencileri ile birlikte müzenin Herbaryum kısmında” açıklaması (s. 87, resim altyazısı) bir yakıştırmadır. Jeolojik zaman panosu önünde, mikroskop başındaki grup fotoğrafı Müze ile aynı katta bulunan "Doğal bilimleri amfitiyatrosu” denilen derslikte çekilmiş olmalıdır. ${ }^{63}$ Okulun 25 . kuruluş yılı (1911) töreninde çekilen ve kitaptaki altyazısında “J.J. Manissadjian... Pontos Kulübü ve Şavarşan Cemiyeti öğrencileri ile birlikte" açıklaması olan fotoğrafta Prof. Ohannes Manisacıyan yer almamaktadır. ${ }^{64}$

Müzeyi içeriden gösteren fotoğrafların bulunamamış olması bir eksiklik olarak not edilmelidir. ${ }^{65}$ Müze binasının taban alanının yaklaşık $300 \mathrm{~m}^{2}$ (14 x 21 m.) olduğu bilinmektedir. Buna göre, üçüncü katta yer alan amfitiyatro, iki küratör odası ve merdiven boşluğu/sahanlığı ile birlikte düşünüldüğünde müze salonunun $100 \mathrm{~m}^{2}$ kadar olduğunu varsayabiliriz. Yine pencere aralıklarına yerleştirilmiş olması gereken, Tarsus Amerikan Koleji'ndeki orijinal dolapların genişliği bu konuda bir fikir vermektedir.

Yazarların, İngilizceden çevirdikleri pasajlara sıkça kendi yorumlarını ekledikleri dikkati çekmektedir:66 Örneğin, kitapta Prof. Arakel Sıvaslıyan'ın iki astronom "aracılığıyla elde ettiği parçalardan 6,5 inch'lik bir teleskop yaptığı" yazılıdır. Oysa, Kolej' in yıllık raporunda okul için birteleskopun satın alındığı bilgisi vardır. ${ }^{67}$ Aynı yerde, Sıvaslıyan'nın doktora tezinin Definitive Determination of the Orbit of Comet 1892 III (Holmes Nov. 6) olması gereken başlığında

62 Alçıtepe ve Alçıtepe, J.J. Manissadijian, 59 (plan).

63 Manisacıyan, Müze Kataloğu’ndaki notlarında mineral ve kayaç örneklerinden üçyüzünün (1-300) “Öğretmen masasının çekmecelerinde" olduğunu not etmiştir (s. 141). Bu masa ve örnekler doğa bilimleri amfitiyatrosunda olmalıdır.

64 Alçıtepe ve Alçıtepe, J.J. Manissadijian, 64 (resim) "J.J. Manissadjian" olarak gösterilen ve göğsündeki kordonda "Medicine" yazan (ikinci sırada soldan dördüncü / fesli Türk subayı ile Prof. Hovhannes V. Hagopyan'ın arasındaki) kişi Ohannes Manisacıyan değildir.

65 Merzifonlu fotoğrafçı Dildilyan'ın iç mekanlarda çektiği resimler vardır. Anadolu Koleji Müzesi'nin içini fotoğraflamamış olması düşünülemez: bkz. Armen T. Marsoobian, Reimagining a Lost Armenian Home: The Dildilian Photography Collection, (London: I.B. Tauris, 2017). Manisaciyan'ın da fotoğraf çektiği bilinmektedir.

66 Bir başka örnek: "Bütün canlılar, anatomi, fizyoloji ve diğer özellikleri bakımından karşılaştırılmalı olarak incelenmektedir" biçiminde çevrilebilecek bir cümle (A comparative study of all living beings is made in relation to anatomy, phsiology and other problems.), başına ve sonuna yapılan eklemelerle: "Laboratuar ortamında bitki ve hayvan canlı örnekleri üzerinde anatomik, fizyolojik çalışmalar yapılmakta, türler sinıflandirllmaktadır" olmuştur (vurgu eklendi), Alçıtepe ve Alçıtepe, J.J. Manissadijian, 43.

67 The Anatolian, 1912-13, Marsovan Turkey, 32. Teleskop ve ek parçaları Anadolu Koleji adına, Sivasliyan'ın ABD'nde çalışıı̆ı $ı$ Goodsell Gözlemevinin direktörü William W. Payne tarafından satın alınmıştır. (We are pleased to announce the purchase of a new telescope for the College, a good six-inch (sic) object-glass refractor by Professor W.W. Payne). 
kuyrukluyıldızınadıunutulmuştur. ${ }^{68}$ AnadoluKoleji’ninbirdiğerdoktoralı̈öğretmeniProf.Yani G. Statiropluos'tan ise hiç söz edilmemiştir. ${ }^{69}$

Kitapta “J.J. Manissadjian’ın... editörlüğünü yaptığı kartpostallar” olduğunun belirtilmesi, ${ }^{70}$ yazarların Ohannes Manisacıyan'1 İsviçre'de yaşayan ve yayıncılık yapan kardeşi Haygazun B. Manisacıyan (1876-1912) ile karıştırdıklarını göstermektedir. Buna karşılık, Ohannes Manisacıyan'ın filatelist olduğu belirtilmemiştir. Kitapta, müfredat tablolarındaki ders adları eksik ve yanlıştır. ${ }^{71}$ Örneğin, psikoloji (psychology) fizyoloji olarak çevrilmiş; Türkçe ders programında "Berahin" olarak gösterilen bir dini metin dersi ([W. Parley] Evidences of Christianity ) tabloya alınmamıştır. ${ }^{72}$

\section{Müze Kataloğu'nun yayımında yapılan yanlışlar}

Kitabın İkinci Bölümünde, Prof. Ohannes Manisacıyan tarafından hazırlanan Anadolu Koleji’nin Müze Kataloğu'na yer verilmiştir. Elyazısı kataloğun tıpkıbasımı yapılmamış, içeriği yeniden dizilerek basılmıştır (s. 107-152). Kataloğun yeni basımında, aktarım sırasında "ortaya çıkabilecek olası yanlışlar dolayısıyla" tabloların aslına sadık kalınarak [İngilizce] verildiği bildirilmiştir (s. 106). Ancak, aktarımda ciddi hatalar yapılmış, örneğin "satın alınarak müzeye konulan numunelerin maddi değeri, karşılarına İngiliz poundu (sic) baz alınarak yazılmıştır” (s. 105) denilerek, Manisacıyan’ın £tq, $\mathfrak{£ t ~ v e ~} \mathfrak{£ T}$ olarak yazdığı "Livre turque", yani Türk/Osmanlı Altın Lirası, yabancı bir para birimi olan İngiliz Poundu/ Sterlini ile karıştırılmıştır. ${ }^{73}$ (Savaş koşullarında, genellikle ABD doları ve İsviçre Frangı ile işlem gören altın ve kâğıt Türk Lirası değerlerinde değişkenlik görülmüştür. ${ }^{74}$ )

68 Şeref Etker, “Türkiye'de İlk Doktoralı Gökbilimci: Arakel G. Sivaslıyan,” Cumhuriyet Bilim Teknoloji; say1 1446 (5 Aralık 2014): 19; Şeref Etker, "Doktorayi asdicanin diratsadz Turkio araçin asdğakedi Arakel G. Sivaslıyan," (çev. Aram Kamburyan,) Nor Marmara, sayı 10665, 9 Aralık 2014, 1; Şeref Etker, "21 Ağustos 1914’te Trabzon'da (Gözlenemeyen) Tam Güneş tutulması,” Osmanlı Bilimi Araştırmaları 16, 1 (2014): 100105. A.G. Sıvaslıyan'ın tezi matematik ve astronomi değil, yalnız astronomi konuludur.

69 Yani G. Statiropulos (Yuannis Gavriil Stateropoulos, 1875-1971) Merzifon'dan ABD'ne giderek Yale Üniversitesi'nde 1905 yılında kimya doktoru derecesini almıştır: bkz. Şeref Etker, "Yurtdışında Kimya Doktorası Yapan Türklere Ek," Osmanlı Bilimi Araştırmaları 21, 1 (2020): 201-203.

70 Alçıtepe ve Alçıtepe, J.J. Manissadijian, 60. Altyazısında “J.J. Manissadjian'ın hazırladığı bir kartpostal” (s. 9) Dildilyan tarafından çekilen bir fotoğraftır ve H.L. Nerso tarafından Merzifon'da basılmıştır.

71 Alçıtepe ve Alçıtepe, J.J. Manissadijian, 39-40.

72 [Merzifon Anatolya Koleci, 1330/1914], 8-9. Anadolu Koleji’nin rehberinde ayrıca şu açıklama vardır: "Ulum-1 diniyeye aid tedrisat bahs ve münazaradan azade, sırf serbesti-i vicdan esasına müsteniddir. Talebe, Kolec Nizamname-i Esasisi mucibince sabahları duada ve Pazar günleri saat üç ve yedide vuku bulan hidemat-1 ruhaniyede hazır bulunurlar... Fakat talebe-i İslam, Kitab-1 Mukaddes derslerini İngilizce lisanile tedris etmeğe mümarese kesb edene kadar bundan muafdırlar." [Merzifon Anatolya Koleci, 1330/1914], 5.

73 Yazarlara inanmak gerekirse, Merzifon'da rüşvetler bile pound cinsinden verilmektedir!: bkz. Alçıtepe ve Alçıtepe, J.J. Manissadijian, 64-65. Kaynak gösterilen kitapta £T (Türk Lirası) ve Lira yazılıdır, Bertha B. Morley, Marsovan 1915: The Diaries of Bertha B. Morley, 2nd. ed., ed. Hilmar Kreiser (Ann Arbor, MI: Gomidas Institute, 2000), 19, 55.

74 Kanunla, kâğıt ve altın Türk Lirası 100 kuruşa eşitlenmiştir; 1 £T = 4,40 \$. Ancak, 1917 'nin başlarında 265 kâğıt kuruşa 1 altın Lira alınabilmektedir. Aynı yılın Temmuz ayına gelindiğinde, 1 altın Lira 4 kâğıt Liraya kadar yükselmiştir: bkz. Melek Öksüz, “Amerikan Belgelerine Göre Birinci Dünya Savaşı Sırasında Osmanlı 
Kitapta yer verilen Müze Kataloğu'nun sayfa düzeninde, sıra sayılı örneklerle bunlara ait notların (Remarks) karşı karşıya getirilmesine dikkat edilmemiştir. Dolayısıyla, kitapta yeniden dizgisi yapılan Müze Kataloğu'nun, SALT Araştırma / ABCFM Arşivindeki dijital kopyasından daha kullanışsız olduğunu söylemek zorundayı. ${ }^{75}$ Bu bölümün hatalı mizanpajı nedeniyle, örneğin Manisacıyan'ın deniz anemonları Actinia equina L. için düştüğü: “Güzel doğal renkleri alkol içinde kayboldu" notunu görüp okumak olanaksızdır. ${ }^{76}$ Kitaba bir dizin hazırlanmamış olması da metin içinde isim/konu aranmasını güçleştirmiştir.

Müze Kataloğu kitaba aktarılırken çok sayıda okuma ve yazım yanlışı yapılmıştır. Bunların doğru okunuş veya yazımları ile eksikler aşağıdaki tabloda gösterilmiştir:

\begin{tabular}{|c|c|c|}
\hline $\begin{array}{c}\text { Katalog } \\
\text { sayfasi }\end{array}$ & Yanlış/Eksik & Doğru \\
\hline 8 & $\begin{array}{l}\text { Felis catus ferus } \mathrm{S} \\
\text { Felis catus domestica } \mathrm{S} \\
\text { Canis luphus } \mathrm{S}\end{array}$ & $\begin{array}{l}\text { Felis catus ferus L. (Linnaeus) } \\
\text { Felis catus domestica L. (Linnaeus) } \\
\text { Canis lupus L. (Linnaeus) }\end{array}$ \\
\hline 9 & $\begin{array}{l}\text { Proverbial enemy of the flooks } \\
{[\mathrm{T}] \text { he price stands for exchange }}\end{array}$ & $\begin{array}{c}\text { flocks } \\
\text { for expense }\end{array}$ \\
\hline 10 & $\begin{array}{l}\text { Puckorius foetidus } \\
\text { Lutra vulgaris End. } \\
\text { Sciurus vulgaris Ehbg. }\end{array}$ & $\begin{array}{c}\text { Putorius foetidus } \\
\text { Lutra vulgaris Erxl. (Erxleben) } \\
\text { Sciurus vulgaris Ehrbg. (Ehrenberg) }\end{array}$ \\
\hline 11 & $\begin{array}{c}\text { Taxidae americana Bird } \\
\text { Talpa europaea } S \\
{[\mathrm{I}] \mathrm{t} \text { can quickly buy the lower part of its body }}\end{array}$ & $\begin{array}{c}\text { Taxidae americana Baird } \\
\text { Talpa europaea L. (Linnaeus) } \\
\text { bury the lower part of its body }\end{array}$ \\
\hline 15 & in small flucks & flocks \\
\hline 16 & $\begin{array}{l}\text { Bubo maximus Libb } \\
\text { Gypus fulvus }\end{array}$ & $\begin{array}{l}\text { Bubo maximus Sibb. (Sibbald) } \\
\text { Gyps fulvus }\end{array}$ \\
\hline 18 & Coccytes glandarius $\mathrm{S}$ & Coccytes glandarius L. \\
\hline 19 & $\begin{array}{c}\text { European... (okunamamış) } \\
\text { gigantic hills } \\
\text { secretes } \\
\text { from } 40^{\prime} \mathrm{S} \\
\text { in the adventure } \\
\text { extable nests }\end{array}$ & $\begin{array}{c}\text { European cuckoo } \\
\text { bills } \\
\text { excretes } \\
\text { from } 40^{\circ} \mathrm{S} \text { (South) } \\
\text { in the structure } \\
\text { eatable nests }\end{array}$ \\
\hline
\end{tabular}

Devleti'nde Para Politikası ve bu Doğrultuda Yapılan Düzenlemeler,” Türkiyat Mecmuası 26, 1(2016): 233-266. Manisacıyan'ın örnekler için, altın Türk Lirası olarak 1917 güzünün rayiç bedellerini gözettiği varsayılabilir.

75 Sayfa düzeninde bitişik olması gereken tablolar ayrılarak karışıklık yaratılmıştır. Örneğin, 109. sayfadaki iki tablo bir bütün olarak okunmalıdır. Müze kataloğunun SALT Araştırma sitesindeki dijital kopyasının doğru okunabilmesi için de çift sayfalar solda ve tek sayfalar sağda olmak üzere, aynı ekranda iki sayfanın birden görülebilmesi gereklidir. https://archives.saltresearch.org/handle/123456789/42920

76 Katalog, 52-53. "Sea-anemons Actinia equina L. Where found: Mediterranean. Distribution: Warm seas. Remarks: Lost in alcohol their natural beautiful colors. Collected near Beyrouth by Dr. L.[evon Karekin] Sewny \& Dr. H. [agop Serope] Eminian". Alçıtepe ve Alçıtepe, J.J. Manissadijian, 39-40. Aynı biçimde, Müze kataloğunun 52. sayfasındaki "Centipeds (Kırkayak), Locust (Çerkirge), Leeches (Sülük). Merzifoun" karşısına 53. sayfadaki "Collected" ([Merzifon'da] toplandı) notu gelmelidir. 


\begin{tabular}{|c|c|c|}
\hline 20 & $\begin{array}{c}\text { Aegithalus (Parns) pendulinus Vig. } \\
\text { Pica candaxa Ray } \\
\text { (Aktarımda 87, } 88 \text { ve } 89 \text {. siradaki kuşların } \\
\text { yer değiştirmesi sonucu Buzzard (Şahin), Buteo } \\
\text { vulgaris için verilen bilgi Owl (baykuş), Otus } \\
\text { vulgaris karşısına gelmiş.) }\end{array}$ & $\begin{array}{l}\text { Aegithalus (parus) pendulinus Vig. } \\
\text { Pica candata Ray. }\end{array}$ \\
\hline 22 & $\begin{array}{c}\text { Columbo oenas } \mathrm{S} \\
\text { Phasianus pietus } \\
\text { Galeatus Vicill. }\end{array}$ & $\begin{array}{c}\text { Columbo oenas L. } \\
\text { Phasianus pictus } \\
\text { Casuarius galeatus Vieill. }\end{array}$ \\
\hline 23 & Australian... (okunamamış) & Australian Emu \\
\hline 26 & Hystrix cristata & Hystria cristata \\
\hline 27 & $\begin{array}{c}\text { dead specimens, already... (okunamamış) } \\
\text { prehensible }\end{array}$ & $\begin{array}{l}\text { already putrid } \\
\text { prehensile }\end{array}$ \\
\hline 30 & Pristis pectinatus Sath. & Pristis pectinatus Lath.[am] \\
\hline 31 & $\begin{array}{c}\text { Silk was inherited in China } 2000 \text { BC. In } 555 \\
\text { two monks brought eggs in hollow... to Cons- } \\
\text { tantinople, inhence it came } 711 \text { to Spain and } \\
\text { Portugal... }\end{array}$ & $\begin{array}{c}\text { Silk was cultivated in China. In } 555 \text { two monks } \\
\text { brought eggs in hollow canes to Constantinople, } \\
\text { whence it came } 711 \text { to Spain and Portugal... }\end{array}$ \\
\hline 34 & Pictmeson Case D & Pictures on Case D \\
\hline 36 & Telmatosaurus & Taumatosaurus \\
\hline 37 & thickness, at have & thickness, at base \\
\hline 40 & Cuttle-bone from a Sephia & Sepia \\
\hline 41 & as came as & as cameos \\
\hline 42 & Anodonta cygnea piscinalis Kils. & Anodonta cygnea piscinalis Nils.[on] \\
\hline 46 & $\ldots($ eksik $)$ & Cypraea pantherina Soland \\
\hline 48 & Lancelet... (eksik) & the lowest form of vertebrate animals \\
\hline 49 & $\begin{array}{l}\text { [Rabbit] Cerebrum little developed, no distinct... } \\
\text { (eksik) } \\
\text { [Twin kids (abnormity)] One head with } 2 \text { mouths, } \\
4 \text { ears... }\end{array}$ & $\begin{array}{l}\text { no distinct convolutions (furrows). } \\
\text { One head with } 2 \text { snouts, } 4 \text { ears... }\end{array}$ \\
\hline 50 & $\begin{array}{c}\text { Torpedo ocellata Kud. } \\
\text { Anadonta cygnae Mills }\end{array}$ & $\begin{array}{l}\text { Torpedo ocellata Rud.[olphi] } \\
\text { Anadonta cygnae Nils.[on] }\end{array}$ \\
\hline 51 & [Teredo navalis L.] Very destinctive to ships... & very destructive \\
\hline 52 & $\begin{array}{c}\text { Centipeds, leeches, etc. } \\
\text { Stowfishes, Sea cucumbers }\end{array}$ & $\begin{array}{l}\text { Centipeds, locusts, leeches, etc. } \\
\text { Starfishes, Sea urchins (eksik), Sea cucumbers }\end{array}$ \\
\hline 53 & Bothriocephalus latus (from fishes) & Botriocephalus latus (from fishes) infest man \\
\hline 54 & $\begin{array}{c}\text { College attire } \\
\text { Casuarius galeatus Vicill } \\
\end{array}$ & $\begin{array}{c}\text { College attic } \\
\text { Casuarina galeatus Vieill } \\
\end{array}$ \\
\hline 55 & $\begin{array}{l}\text { It is supposed to belike the "kookh" of the } \\
\text { Arabian Night Tales }\end{array}$ & $\begin{array}{c}\text { It is supposed to belike the "Rookh" [Anqa/Anka] } \\
\text { of the Arabian Night Tales }\end{array}$ \\
\hline 57 & As it has not many enemies & As the shark has not many enemies... \\
\hline 58 & $\begin{array}{l}\text { Yakmar of Baroda } \\
\text { Pound } \\
\end{array}$ & $\begin{array}{l}\text { Gakwar (Gaekwar) of Baroda } \\
\text { £t (Türk Lirası) }\end{array}$ \\
\hline 60 & $\begin{array}{c}\text { Hemitera } \\
\text { Beetles .... (eksik) } \\
\end{array}$ & $\begin{array}{c}\text { Hemiptera } \\
\text { Beetles (Coleoptera) } \\
\end{array}$ \\
\hline 61 & The 2 various in Box 8 are moths & The 2 Uramas in Box 8 are moths. \\
\hline 65 & [Celtis australis] Bernies eatable & Berries eatable. \\
\hline 66 & Amygdalus orientalis Mill. & Amygdalus orientalis Ait. \\
\hline 67 & $\begin{array}{l}\text { [Sour cherry, Prunus cerasus] The name is } \\
\text { derived from Kerasund, whence it was stonght } \\
\text { to Europe }\end{array}$ & $\begin{array}{c}\text { Kerasund (Giresun), whence it was brought to } \\
\text { Europe. }\end{array}$ \\
\hline
\end{tabular}




\begin{tabular}{|c|c|c|}
\hline 69 & [Tamarix spec.] Ashingent & astringent \\
\hline 77 & $\begin{array}{c}\text { Junglandales } \\
\text { Fagaceae ..... (eksik) } \\
\end{array}$ & $\begin{array}{c}\text { Juglandales } \\
\text { Fagaceae (Cupuliferae) } \\
\end{array}$ \\
\hline 79 & ....... (Hypericaceae) (eksik) & Guttiferae (Hypericaceae) \\
\hline 80 & Sayfa sonunda eksik bilgi & Value £.T. (Livre turque) 11.50 \\
\hline 83 & Xerophytas & $\begin{array}{c}\text { Hysterophyta } \\
\text { Takım (Ordo) ve aile (Familya) isimleri } \\
\text { bir satır kaydığı için kitabın bu sayfasında verilen } \\
\text { tablo Müze Kataloğu'na uymamaktadır. }\end{array}$ \\
\hline 86 & Belotenthis Schubberi An. & Beloteuthis schübleri Qu. \\
\hline 97 & $\begin{array}{l}\text { Türkiye fosillerinin toplandığı yerlerle, örnek- } \\
\text { lerin jeolojik dönemleri karşılaştırmalı olarak } \\
\text { veren tabloda } \\
\text { diziler kaydığı için Müze Kataloğu'na uygun } \\
\text { değildir. }\end{array}$ & \\
\hline 101 & .... (okunamayan isim) & Dr. Kirschandl \\
\hline 156 & & $\begin{array}{l}\text { Katalog indeksinin sayfa numaraları gösterilme- } \\
\text { miştir. }\end{array}$ \\
\hline
\end{tabular}

Kuşkusuz, Müze Kataloğu'nun yayımında en önemli eksiklik, Manisacıyan'ın Anadolu Koleji doğa tarihi koleksiyonun oluşumunu özetlediği bir sayfalık Giriş (Introduction) bölümünün Türkçeye çevirilmemiş olmasıdır. ${ }^{77}$ Müzenin kuruluşuyla ilgili olarak irdelenmesi gereken birincil kaynak Manisacıyan imzalı bu metindir. Manisacıyan'ın Girişinden bir cümle Türkçeye çevrilmiş, o da yanlış çevrilmiştir. ${ }^{78}$ Kataloğun bu bölümü, özellikle (1880'lerden başlayarak) Charles C. Tracy’nin koleksiyonun oluşturulması ve Müze’nin kuruluşundaki rolünü aydınlatmaktadır. Prof. Ohannes Manisacıyan Anadolu Koleji Müzesi'nin küratörüdür, ${ }^{79}$ ama yazarların önerdikleri gibi, "her parça bizzat Manissadjian tarafından incelenip tanımlanmıştır” denilemez. ${ }^{80}$ Manisacıyan'ın değinilen, bu dönemdeki yazışmalarının önemli bir kısmı örneklerin tanımlanmasıyla ilgilidir.

\section{Prof. Ohannes Manisacıyan, böcek, kelebek, bitki ve fosil toplayıcısı}

Kitabın Üçüncü Bölümünde, Manisacıyan “bir bitki toplayıcısı” olarak tanıtılmıştır. Topladığı bitkilere gelince, yazarlar, "Anatolia College Herbayumun'dan geriye bir şey kalmamıştır" denildikten sonra, ${ }^{81}$ Avrupa ve ABD’ndeki 24 herbaryumda Manisacıyan tarafindan toplandığ

77 Anadolu Koleji Müzesi Kataloğu, 3-5; Alçıtepe ve Alçıtepe, J.J. Manissadijian, 107.

78 Alçıtepe ve Alçıtepe, J.J. Manissadijian, 87'deki ifade: "Sergilenen yerin kapısına İngilizce ve Ermenice 'Biz Kardeşiz’ yazısı asılmıştı.” Doğru çeviri: "Müzeye, 1895 mezunları tarafından ceviz ağacından yapılmış iki dikey vitrin bağışlandı; vitrinlerin üzerinde İngilizce ve Ermenice olarak sınıfın mottosu olan 'Bizler kardeşiz' yazılıydı." (Katalog, s. 3).

79 Kataloğun önsözünü "Küratör” (The Curator) olarak imzalayan Manisacıyan, bu bölümün içinde kendisi için "eski küratör" (former curator) demiştir.

80 Alçıtepe ve Alçıtepe, J.J. Manissadijian, 81.

81 Alçıtepe ve Alçıtepe, J.J. Manissadijian, 160-161, 173. 
belirlenen örneklerin adları sıralanmıştır (s. 173-187; 188-191). ${ }^{82}$ Buna karşılık, Anadolu Koleji Müzesi'nden Ankara Üniversitesi Fen Fakültesi Herbayumu'na (ANK) geçen koleksiyondan hiçbir bitki örneğinin adı verilmemiştir. Manisacıyan'ın topladığı bitki örneklerinin Herbarium Turcicum içine alınmasında Ankara Yüksek Ziraat Enstitüsü’nde Botanik Profesörü olan Kurt Krause'nin rolünün araştırılması gerektiği kanısındayız. ${ }^{83}$

Manisacıyan'ın Müze Kataloğu'nun içindeki notlarından 1876' da önce böcek toplamaya başladığını öğreniyoruz (Katalog, s. 61) ${ }^{84}$ Bundan bir yıl önce, 1875 yazında Alman entomolog Otto Staudinger Amasya ve çevresinde böcek ve kelebek toplamaya gelmiş ve Manisacıyan ailesinin 13 yaşındaki meraklı büyük oğlu Johann (Ohannes) bu gezisinde ona rehberlik yapmıştır. ${ }^{85}$ Böylece başlayan ilişkinin Manisacıyan'ın doğa bilimlerine yönelmesinde etkili olduğunu düşünebiliriz. 1888'de bir güve türüne Manisacıyan'ın adını: Polymixis manisadjiani veren Staudinger (1881), ${ }^{86}$ onun Berlin'e gelmesini de desteklemiş olmalıdır. Manisacıyan, Otto Staudinger'in 1900 yılında ölümüne kadar bu işbirliğini sürdürecektir. ${ }^{87}$

Manisacıyan'ın Müze'nin açılışında Anadolu Koleji'ne 1913'te bağışladığı zengin bir böcek koleksiyonu vardır ve bu koleksiyonun en değerli kısmı, Manisacıyan tarafından toplanan 1.200 kadar kelebek ve güve örneğidir (variyete). Aralarında daha önce bilinmeyen türler vardır. ${ }^{88}$ Manisacıyan'ın son sayımına göre ise, Doğa Tarihi Müzesi’nde 3.002 böcek, kelebek ve güve örneği bulunmaktadır ve Müze'nin en geniş koleksiyonunu oluşturmaktadır. Bu örneklerin \%90’1 Türkiye'den toplanmıştır.

82 Bu liste tam olmayıp, örneğin Vermont Üniversitesi, Pringle Herbarium (VT) koleksiyonundaki Manisacıyan'ın Bromus squarrosus L. örneği saptanamamıştır. http://intermountainbiota.org/portal/collections/individual/ index.php?occid $=7233963 \&$ clid $=0$

83 Bkz. Asuman Baytop, "Prof. Kurt Krause'nin (1883-1863) Türkiye Florası ile İlgili Gezileri ve Yayınları," Osmanlı Bilimi Araştırmalart 9, 1-2 (2007-2008): 171-182.

84 Alçıtepe ve Alçıtepe, J.J. Manissadijian, 133. "The species [beetles] from Asia Minor have been collected by J.J.M. from 1876 to 1914..." (J.J.M. [Manisaciyan] tarafindan 1876'dan 1914'e kadar Anadolu'dan toplanan böcek türleri).

85 Otto Satudinger. Lepidopteren-fauna Kleinasien's: Horae Societatis entomologicae rossicae (St. Petersburg) 14 (1879): 176-482;

"Ihr damals dreizehnjähriger ältester Sohn Johann (Ohannes), ein höchst intelligenter Knabe, der auch viel Interesse fur unsere Beschäftigung zeigte, wurde von mir zur Begleituing und Hülfeleistung engagiert, und leistete uns besonders auch durch seine Sprachkenntniss (er sprach ebenso gut türkisch und armenisch wie deutsch) manche sehr gute Dienste." (s. 197). Staudinger'in anlatımına göre, Almanlar yaklaşık elli yıldır Amasya çevresinde ipekçilik yapmaktadır. Ohannes'in annesi de Amasya'da yaşayan Protestan cemaatinden Klein ailesinin kızıdır. Staudinger, Manisacıyan adının Almanca okunuşunu "Manisadschian” olarak vermiştir. (s. 197).

86 Polymixis manisadjiani Stgr. [Staudinger] Otto Staudinger. "Lepidopteren-fauna Kleinasien's," Horae Soc. ent. ross., 16 (1881): 65-135. Ayrica, Polia manissadjiani Stgr. Otto Staudinger. "Centralasiatische Lepidopteren," Entomologische Zeitung Stettin 49 (1888): 1-65.

87 Alçıtepe ve Alçıtepe, J.J. Manissadijian, 88. Manisacıyan'ın Freyn, Staudinger, Förster vd. Avrupalı bilim insanlarıyla takas yaptığını belirtmek için gösterilen kaynak (Bölüm 2, dn. 25) konuyla ilgisizdir.

88 The Anatolian, 1913-14, Marsovan Turkey, 28. 
Yine katalogda verilen sayılara göre, bitki örneklerinin toplamı 1.382'dir ve bunun \%60 kadarı Türkiye'den toplanmıştır. Koleksiyondaki 2.000 mineral ve kayaç örneğinin ancak \%45'i Türkiye'de toplanmıştır. Müzenin 15 vitrininden beşi fosillere (Petrefact) ayrılmıştır. Manisacıyan'ın kendisine getirilen bazı fosil örneklerini Türkiye dışındaki koleksiyonlara ilettiği bilinmektedir. ${ }^{89}$ Kitapta, Müze'ye katkıda bulunanların isimlerinin gruplandı̆̆ 1 tabloda "Türkiye'den toplanan fosiller" başlığı altında mineraloji ve petrografinin de alınması bir karışıklık yaratmıştır. ${ }^{90}$ (Petrografi genel olarak jeolojik materyalin mikroskopik incelemesinin yapıldığı bir disiplin; mineraloji ise özel olarak mineralleri inceleyen bir bilim dalıdır.) Ohannes Manisacıyan'ın paleontolojiye olan özel ilgisi, adının 1928'de bir Cephalopod (Cenoceras) türüne verilmesiyle kanıtlanmıştır: Nautilus manissadjiani ${ }^{91}$

Manisacıyan, Flora Anatolica adını verdiği herbaryumunu, Anadolu Koleji Müzesi'nin içinde bir vitrine Türkiye'den (K. "Turkey"), ${ }^{92}$ bir dolaba da Almanya'dan (F. "Plants from Germany”) toplanan örnekleri ayırarak yerleştirmiştir. Yazarların, "Manissadjian'ın kişisel dolabında saklanan bitkiler" (s. 171) ile "Almanya'dan getirilen bitkiler" (s. 172) olarak ayırdıkları örnekler aynı koleksiyon içindedir. ${ }^{93}$ Bugün, Ankara'da ve Türkiye dışındaki herbaryumlarda J.J. Manissadjian etiketi altında iyi korunmuş bitki örneklerine bakarak, onu yalnızca "bitki toplayıcısı” olarak tanıtmak kitabın önemli bir eksiği sayılmalıdır.

Kitapta, Manisacıyan'ın “zaman zaman Merzifon'un meteorolojisiyle ilgili çalışmalar yap[tığı]” bilgisi yanıltıcıdır.94 Manisacıyan'ın Anadolu Koleji'nde kurduğu meteoroloji istasyonunda, 1892'den başlayarak düzenli gözlemler yapılmış ve hazırlanan klimatoloji tablolarını 1910'a kadar yirmi yıla yakın bir süreyle, kısa raporlar halinde yayımlanmıştır. Anadolu Koleji'nin verileri, iklim değişikliğinin yaşandığg çağımız için birer referans oluşturmaktadır.

89 Kitapta, yanlış olarak Buliminus phazemonicus örneğinin Bern'de Naturhistorisches Museum'da olduğu bildirilmiştir: Alçıtepe ve Alçıtepe, J.J. Manissadijian, 88, 90. Rusya'da bulunup Merzifon'dan Manisaciyan tarafindan Almanya'da Paul Hesse'ye gönderilen örnek, bugün ABD'nde Academy of Natural Sciences of Drexel University, Philadelphia'dadır: bkz. Francisco J. Borrero, Gary Rosenberg, "The Paul Hesse Collection at the Academy of Natural Sciences of Philadelphia, with a review of names for Mollusca introduced by Hesse," Proceedings of the Academy of Natural Sciences of Philadelphia 164 (2015): 43-100.

90 Alçıtepe ve Alçıtepe, J.J. Manissadijian, 93.

91 Odomar Gugenberger. "Beiträge zur Geologie Kleinasiens mit besonderer Berücksichtigung des anatolischen Lias," Sitzungsberichte der Akademie der Wissenschaften in Wien, mathematisch-naturwissenschaftichen Klasse. Abteilung I, 137, 3-4 (1928): 259-282, Tafln. I, II.

92 Manisacıyan, bu örnekler arasında K. Vensan Aznavur aracılığıyla Türkiye dışından gelen örnekler de olduğunu belirtmiştir (Katalog, s. 76).

93 F.[Friedrich] Förster tarafindan Manisacıyan'a bağışlanan 532 örnekten oluşan koleksiyon Müze’ye verilmiştir (Katalog, s. 82-83). Kitapta belirtildiği gibi bir ödeme yapılmamıştır: Alçıtepe ve Alçıtepe, J.J. Manissadijian, 166. Kitapta, Manisaciyan'ın kataloğunda “Almanya'dan gelen bitkiler" listesinde yer alan örnekler (F dolabı, s. 143-144), "Manissadjian'ın kişisel dolabında saklanan bitkiler” başlığı altında (s. 171-172) iki kez dizilerek verilmiştir; fakat, dizgideki özensizlik yüzünden, aynı tablolardaki örnek toplamları farklı (561 ve 539) olduğu gibi, Katalogda (s. 83) verilen toplamdan (532) fazladır.

94 Alçıtepe ve Alçıtepe, J.J. Manissadijian, 60. 
Manisacıyan'ın Müze Kataloğu'ndaki notlarından bir bölümü değerlendirilmemiştir: Müze binasının inşaatı bağışlarla gerekleştirilirken, Manisacıyan'ın gezileri ve saha araştırmalarının desteklenmesi için, Kolej bütçesinden "özel bir fon” oluşturulmuştur (Katalog, s. 4). Anadolu Koleji Müzesi'ne yapılan bağışlar arasında Talas, Kayseri’de görevli Henry K. [Knowles] Wingate'in gönderdiği bir ağaç örnekleri seti vardır. İkiye ayrılan bu ağaç setinin diğer yarısı Talas'taki müzede kalmıştır (Katalog, s. 71). Buradan, 1889'da kurulan Talas Amerikan Okulu'nda da bir müze (Talas Museum) olduğunu öğreniyoruz. ${ }^{95}$

Kitapta, 1888 y1lında “St. Paul's Institute” adiyla kurulan Tarsus Amerikan Koleji'nin "herbaryum materyalleri ile ilgili kataloğu günümüzde Minnesota Historical Society'de Sarah Carmelite Brewer Christie'nin 1882 tarihli otuz ikinci dosyasında saklanmaktadır" denilmektedir. Okulun kuruluşundan öncesine tarihlenen bu belge ile ilgili bir açıklama yoktur. ${ }^{96}$ Sözü edilen katalog incelenmeden sözü edilen koleksiyonun bir "müze" oluşturduğunu söylemek, buradaki bitki örneklerini bir "herbaryum" saymak spekülasyon olur. Bu bölüm bize yalnızca, Türkiye'de doğa tarihi müze ve koleksiyonlarının tarihi üzerindeki çalışmaların yeni olduğunu ve bilinen koleksiyonlardan herhangi birine "ilk müze" denilmesinin yanlış olacağını hatırlatmaktadır. ${ }^{97}$

Manisacıyan'ın katalogdaki elyazısı karakterini dikkate almayan yazarlar, Strasbourg Üniversitesi Herbarium'undaki Digitalis orientalis L. etiketinin onun elinden çıkmış olamayacağını ayırd edememişlerdir. ${ }^{98}$ Bugün Manisacıyan'ın topladığg bitki örneklerinin pek çoğu “A. Manissadjian” adıyla etiketlenmiştir.99 “A." harfinin (inisiyal) Manisacıyan'ın ikinci adının Türkçe söylenişi olan “Agop” olduğuna kuşku yoktur. ${ }^{100}$ Yazarlar, Manisacıyan'ın adını "babasına ithafen (Barsam) Ağa": A.[Ağa/Agha] Manissadjian olarak yazmış olabileceği, gibi garip bir önermede bulunduktan sonra, Agop'un Jacop (Almanca) isminin "Ermenice versiyonu" olduğunu ileri sürmüşlerdir. ${ }^{101}$ Oysa, kitabın sonsözünde (epilog) alıntılanan yazarın adı - Agop isminin Ermeni dilindeki söyleniş biçimiyle ${ }^{102}$ - "Hagop" olarak yazılmıştır. ${ }^{103}$

95 Alçıtepe ve Alçıtepe, J.J. Manissadijian, 139.

96 Alçıtepe ve Alçıtepe, J.J. Manissadijian, 99.

97 Benzer bir durum hayvanat bahçeleri için de geçerlidir: bkz. Feza Günergun. "Türkiye'de Hayvanat Bahçeleri Tarihine Giriş," I. Ulusal Veteriner Hekimliği Tarihi ve Mesleki Etik Sempozyumu Bildirileri. Prof. Dr. Ferruh Dinçer' 'in 70. Yaşı Anisina. Elazığ, 30 Mart-1 Nisan 2006, ed. Abdullah Özen (Elazığ: Firat Üniversitesi, yay., 2006), 185-218.

98 Alçıtepe ve Alçıtepe, J.J. Manissadijian, 165: "Herbier de l'Université de Strasbourg arşivinde bulunan J.J. Manissadjian'ın kendi el yazısı ile hazırlanmış bir herbaryum etiketi".

99 Örneğin, Freie Universität Berlin-Dahlem, Botanisches Garten u. Botanisches Museum koleksiyonunda Manisacıyan'ın toplayıcı olarak adı: A.[gop] Manissadjian, J.[acob] Manissadjian ve J.J. [Johannes Jacob] Manissadjian olarak geçmektedir. http://search.biocase.org/bgbm/search/units/preview/\#716

100 Bkz. Agos, say1 1038, 8 Nisan 2016. http://www.agos.com.tr/tr/yazi/14956/manissadjianin-katalogu-gun-isiginda

101 Alçıtepe ve Alçıtepe, J.J. Manissadijian, 87.

102 Yazarlar, kitabın girişinde de Merzifon Anadolu Koleji Müzesinin "Kurucusu" (doğrusu: Küratörü) olarak "Johannes (Hovhannes), Jacop (Hagop) Manissadjian" adını vermişlerdir: bkz. Alçıtepe ve Alçıtepe, J.J. Manissadijian, 17.

103 Alçııepe ve Alçıtepe, J.J. Manissadijian, 205. 


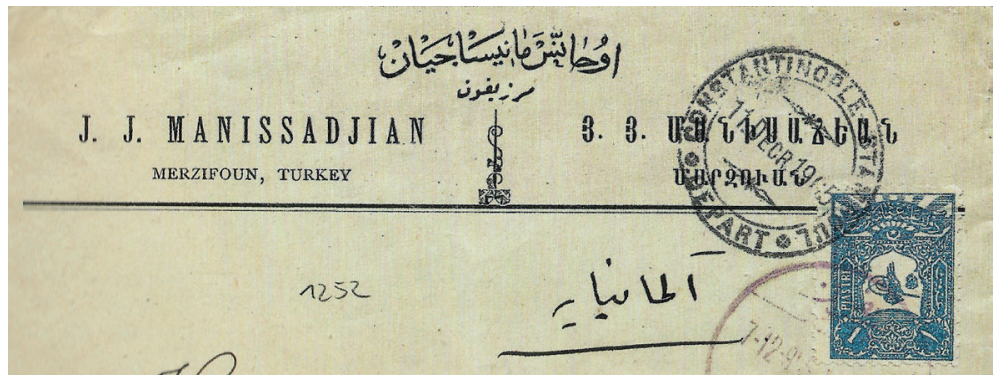

Ohannes Manisaciyan, Merzifon ${ }^{104}$

\section{Sonuç yerine başlangıç}

Ohannes Manisacıyan'ın 19. yüzyılın son yıllarında Mardin'de topladığı güve örnekleri, 21. yüzyılın başında yeniden incelenerek bir türüne onun adı verilmiştir: Amselina manissadjiani (Gozmány 2008). ${ }^{105}$ Prof. Manisaciyan’ın ve Merzifon Anadolu Koleji Müzesi’nin öyküsünü bu türle başlatıp, tarihin çetrefil yumağının içinden ipuçlarını bulup geçmişe doğru çözmeğe çalışmak, bir görev olarak önümüzde durmaktadır. Anadolu'nun Kaybolan Renklerinden Bir Doğa Bilimci J.J. Manissadjian adlı kitabın hazırlanışı aceleye getirilmiş, kaynakları yeterince işlenmemiş, belirli kısıtlarla yayımlanmış; kitaba dayanak yapılmak istenen Manisacıyan'ın hazırladığı Müze Kataloğu incelenmek bir yana, kavranamamış ve kopyalanırken dizgesi bozulmuştur. Kitabın çıkış noktası olan SALT Galata "Boş Alanlar” (2016) sergisi de kısa sürede hazırlanmış ve kurgusunda görselliğe ağırlık verilmiş bir etkinlik olmuştu.

Ohannes Manisacıyan'ın yaşamöyküsü içinde, onun ilgilendiği doğa bilimleri dallarındaki çalışmaları ve koleksiyonları ile ilişkilendirilebilecek bütün belge ve bulguların kapsamlı olarak, ilgili uzmanlarca yeniden ele alınmasıyla Merzifon Anadolu Koleji Doğa Tarihi Müzesi kültürel bir değer olarak toplum ve bilim tarihimizde hak ettiği yeri alabilir. Prof. Manisacıyan'ın ve koleksiyonlarının oluşumuna katkıda bulunanların uğraşıları ve bıraktıkları izler üzerinden doğa bilimleri araştırmaları geleceğe taşınabilir. Evrim, yalnız doğanın değil, doğa tarihinin de bir yasasıdır ve bugüne dek yapılanlar ve yazılanlar yeni bir başlangıç olmalıdır.

104 Dilbilimci Manisacıyan, adının Türkçe’de “Ohannes” olarak doğru okunabilmesi için n (nun) harfinin üzerine bir şedde koydurmayı unutmamıştır, bkz. Gülnur Sandalc1, Mert Sandalcı, Belgelerle Türk Eczacılğl, 18401948, c. I-2, İstanbul, Dr. Nejat Eczacıbaşı Vakfı yay., 2002, s. 178-179.

105 László Gozmány, Microlepidoptera Palaearctica, vol. 13: Symmocidae, ed. Reinhard Gaedike (Keltern: Goecke \& Evers, 2008). Ayrıca, bkz. Ahmet Ömer Koçak ve Muhabbet Kemal, "List of the Lepidoptera of Mardin Province (SE Turkey)" CESA News (Centre for Entomological Studies Ankara) sayı 103 (2015): 27-37. 